\title{
Therapeutic controversies in the management of acute anaphylaxis
}

\author{
Anthony F T Brown
}

At present there are few controlled clinical therapeutic trials in acute anaphylaxis despite the emergence of evidence based medicine. Moreover, the explosive nature, unpredictable onset, and usually rapid response to treatment that characterise acute anaphylaxis mean that this situation is unlikely to change. ${ }^{1}$ The vast majority of serious anaphylactic reactions occur unexpectedly, ${ }^{2}$ typically in fit patients. Anaphylaxis is rarely seen or described in critically ill or shocked patients other than in those with asthma. ${ }^{1}$ Therefore, treatment recommendations have to be based on clinical observation, interpretation of the pathophysiology and, to an extent, animal studies. ${ }^{3}$ However, descriptions of the management of anaphylaxis, for instance those in Hospital Update in $1991^{4}$ and on angio-oedema in the British Medical fournal in $1992,{ }^{5}$ are often then criticised for the treatment recommended. ${ }^{6-9} \mathrm{~A}$ recent expert opinion by Fisher on the treatment of acute anaphylaxis ${ }^{10}$ was followed by no less than 10 letters in response, many of which contained errors of logic as pointed out by Fisher in replying to them. ${ }^{11}$

Clearly there is confusion about the correct management of acute anaphylaxis. Much of the controversy is due to misinterpretation of published reports. In this review I reassess the role, route of delivery, dose, concentration, and efficacy of the various drugs used in anaphylaxis. Adrenaline, steroids, antihistamines, fluids, glucagon, aminophylline, and discharge drugs will be discussed in detail. I shall use the term "anaphylaxis" to refer to both anaphylactic reactions (IgE mediated immediate type hypersensitivity reactions) and anaphylactoid reactions (non-immunologically triggered), as the clinical expression and final mediators involved are identical. ${ }^{12}$ Tables are included giving clear recommendations for first line, second line, and discharge treatment, and allowing rapid evaluation of the drugs involved.

Accepted for publication 18 July 1997

Table 1 Beneficial effects of adrenaline

\begin{tabular}{lll}
\hline$\alpha$ Adrenergic & $\uparrow$ Peripheral vascular resistance: & $\uparrow$ Blood pressure \\
& $\uparrow$ Coronary artery perfusion \\
& $\downarrow$ Peripheral vasodilatation & \\
& $\downarrow$ Angio-oedema & \\
& $\downarrow$ Urticaria & \\
$\beta_{1}$ Adrenergic & Positive inotrope & \\
$\beta_{2}$ Adrenergic & Positive chronotrope & \\
$\beta$ Adrenergic & Bronchodilatation & $\downarrow$ Inflammatory mediator release \\
\hline
\end{tabular}

\section{Adrenaline}

BENEFICIAL EFFECTS

Adrenaline has a pivotal role as first line treatment for acute anaphylaxis. ${ }^{231013}$ Its beneficial effects include $\alpha$ adrenergic stimulation increasing peripheral vascular resistance and improving the blood pressure and coronary artery perfusion, reversing peripheral vasodilatation, and decreasing angio-oedema and urticaria. $\beta_{1}$ Adrenergic stimulation has positive inotropic and chronotropic effects on cardiac activity, and $\beta_{2}$ adrenergic effects include bronchodilatation. ${ }^{14} \beta$ Adrenergic receptors also increase intracellular cyclic adenosine monophosphate (cAMP) production in mast cells and basophils, which inhibits further inflammatory mediator release ${ }^{2131516}$ (table 1).

\section{ROUTES OF ADMINISTRATION}

However, the correct dose and route of administration of adrenaline are unclear. The British national formulary recommends 0.5 to $1.0 \mathrm{mg}$ or 0.5 to $1.0 \mathrm{ml}$ of $1: 1000$ adrenaline intramuscularly as the standard initial adrenaline regime in anaphylaxis. ${ }^{17}$ In America, 0.3 to $0.5 \mathrm{mg}$ of $1: 1000$ adrenaline subcutaneously is recommended, ${ }^{218}$ whereas 0.5 to $0.8 \mathrm{mg}$ subcutaneously is recommended in Sweden. ${ }^{5}$ The clinical effectiveness of these dose variations is not well defined, nor is there convincing evidence for a difference between the intramuscular and subcutaneous routes. $^{3}$ As vasodilatation is the main pathological change early in anaphylaxis, the subcutaneous or intramuscular absorption of adrenaline is rapid and effective. When anaphylaxis is treated early, is mild or progressing slowly, when venous access is difficult, or if the patient is unmonitored, 0.3 to $0.5 \mathrm{ml}$ of $1: 1000$ adrenaline $(0.3$ to $0.5 \mathrm{mg})$ should be given intramuscularly. This has advantages in terms of safety and is usually highly effective. ${ }^{3}$ The adrenaline dose may be repeated every five to 10 minutes, or longer according to the response (table 2).

\section{INTRAVENOUS ADRENALINE}

In more serious cases of anaphylaxis, particularly when the intravascular volume is depleted and shock occurs, or there is severe dyspnoea or airway compromise, the intravenous route is necessary to achieve the rapid, optimal absorption of adrenaline. ${ }^{3}$ Relying on the subcutaneous route in these circumstances is unsatisfactory. Heilborn showed in 12 healthy adult 
Table 2 First line management of acute anaphylaxis

\section{Oxygen}

Adrenaline Early, mild, or progressing slowly, difficult venous access, or unmonitored patient:

Shock, severe dyspnoea, airway compromise, or deteriorating patient. Must be monitored:
$0.3-0.5 \mathrm{mg}(0.3-0.5 \mathrm{ml})$ of $1: 1000$ adrenaline $\mathrm{IM}$, repeated every $5-10 \mathrm{~min}$ according to response

$0.75-1.5 \mu \mathrm{g} / \mathrm{kg}$ of $1: 100000$ adrenaline IV at $10-20 \mu \mathrm{g}$ $\mathrm{min}(1-2 \mathrm{ml} / \mathrm{min})$ initially, repeated according to response

$10-20 \mathrm{ml} / \mathrm{kg}$ for shock

Colloid

was subsequently diagnosed as having had a

IM, intramuscular; IV, intravenous.
subjects that the subcutaneous administration of adrenaline leads to prolonged but variable absorption related to local vasoconstrictor action. ${ }^{19}$ This potential for variability is clearly unacceptable in the shocked or critically compromised patient.

Unfortunately, the use of intravenous adrenaline in anaphylaxis is confused by an even wider variation in proposed doses, ranging from $1 \mu \mathrm{g} / \mathrm{min}^{20}$ to a $2 \mathrm{mg}$ bolus. ${ }^{21}$ Moreover, many clinicians warn that intravenous adrenaline is too dangerous and rarely if ever justified, as it may cause greatly increased systolic and diastolic blood pressures with the risks of intracerebral bleeding, increased myocardial oxygen consumption inducing angina, myocardial ischaemia or even infarction, and cardiac arrhythmias including ventricular fibrillation. ${ }^{4822}$ (table 3). However, these adverse outcomes usually occur when the adrenaline has been given too rapidly, inadequately diluted, or in excessive dose. ${ }^{2324}$ Cases cited from published reports on the apparent dangers of intravenous adrenaline fail to emphasise clearly that other causes such as hypoxia, hypotension, acidosis, or the direct action of the inflammatory mediators released during anaphylaxis may be responsible for the cardiovascular complications. ${ }^{142526}$ For instance, Sullivan described two patients with anaphylaxis given a bolus intravenous injection of $500 \mu \mathrm{g}(5 \mathrm{ml})$ of 1:10 000 adrenaline by paramedics before arrival at hospital. Both patients developed ventricular tachycardia which reverted spontaneously to sinus rhythm. Sullivan concluded that physicians treating anaphylaxis should be aware of possible arrhythmias - spontaneous, adrenaline induced, or from other causes-and that ECG monitoring was desirable. ${ }^{25}$ Roberts-Thomson et al stated in a letter to the Medical fournal of Australia that one patient had a cardiac arrest following intravenous adrenaline for moderate anaphylaxis, so its administration was hazardous and rarely warranted, but they pointed out that if intravenous adrenaline is required it should be given slowly and in high dilution. ${ }^{26}$ Finally, Barach et al describe a 34 year old man stung by a bee who received $500 \mu \mathrm{g}(0.5 \mathrm{ml})$ of 1:1000 adrenaline intravenously over three minutes. He initially developed chest pain, palpitations, and ST elevation on the ECG, and

Table 3 Potential side effects of adrenaline

\begin{tabular}{ll}
\hline Greatly increased systolic and diastolic blood pressure: & $\uparrow$ Risk of intracerebral bleeding \\
$\uparrow$ Myocardial oxygen consumption: & $\uparrow$ Angina, myocardial ischaemia \\
Cardiac arrhythmias & $\uparrow$ Risk of myocardial infarction
\end{tabular}

myocardial infarct related to multiple small vessel disease 24 days later. ${ }^{14}$ In their discussion, they questioned whether agents other than adrenaline may have caused the initial myocardial ischaemia, such as the direct cardiotoxic effect of mellitin in hymenopteran venom. Also, they noted that many of the mediators released in anaphylaxis themselves cause coronary artery vasoconstriction, including histamine (through $\mathrm{H}_{1}$ receptors), platelet activating factor (PAF), leukotrienes, thromboxane $\mathrm{A}_{2}$, and prostaglandin $\mathrm{D}_{2}{ }^{27}{ }^{28}$ Finally, they discuss the benefits of adrenaline and the confusion over dose guidelines, and recommend that in anaphylactic shock adrenaline should be given intravenously in a dilution of $1: 100000$ delivered at $1 \mathrm{ml}$ or $10 \mu \mathrm{g}$ per minute initially, under ECG monitoring. ${ }^{14}$

Thus all three papers discuss important safety issues in the use of intravenous adrenaline and suggest other possible causes for the cardiovascular complications. Unfortunately, these reports are now usually cited as being critical of the use of intravenous adrenaline and as incorrectly implicating it as the sole cause of cardiovascular complications.

1:100 000 DILUTION OF INTRAVENOUS ADRENALINE Many experts currently recommend a similar dilution and dose of intravenous adrenaline to Barach and Nowak for serious anaphylaxis. ${ }^{12} 23242930$ They recommend adrenaline diluted to $1: 100000$ given at 1-2 $\mathrm{ml}(10-20 \mu \mathrm{g})$ per minute at an initial dose of $0.75-1.5 \mu \mathrm{g} / \mathrm{kg}$. This may be followed by an infusion if prolonged treatment is required. "Serious anaphylaxis" includes any patient with hypotension, severe bronchospasm or airway swelling, or deteriorating despite intramuscular adrenaline. Intravenous adrenaline used in this way is logical, safe, and essential, ${ }^{31}$ provided it is given in a resuscitation area under ECG monitoring. ${ }^{11}$ (table 2). The $1: 100000$ adrenaline is prepared by drawing up $1 \mathrm{mg}$ adrenaline (1 $\mathrm{ml}$ of 1:1000 adrenaline) in a $20 \mathrm{ml}$ syringe, and $9 \mathrm{ml}$ saline to give a total volume of $10 \mathrm{ml}$. All but $2 \mathrm{ml}$ of this is discarded (leaving $200 \mu \mathrm{g}$ of adrenaline in the syringe). Saline is again drawn up to a total volume of $20 \mathrm{ml}$, giving a final concentration of $10 \mu \mathrm{g}$ per $\mathrm{ml}$-that is, a 1:100 000 dilution. Alternatively, an infusion of adrenaline may be prepared by putting $1 \mathrm{mg}$ adrenaline in $100 \mathrm{ml}$ normal saline, and running at $60-120 \mathrm{ml} /$ hour using an infusion device (that is, 10-20 $\mu \mathrm{g} / \mathrm{min})$. The rate may be altered or the infusion stopped according to the clinical response. Patients with persistent symptoms 
Table 4 Indications for admission in acute anaphylaxis

Admit all patients with significant reactions, including any who received adrenaline:

If remain unstable, admit to intensive care unit

If stable, admit to monitored observation area for 6-8 hours

(there is a $5 \%$ incidence of a delayed, biphasic response)

,may require a maintenance infusion at 1-5 $\mu \mathrm{g} / \mathrm{min}$ before admission to intensive care. This low dose, high dilution adrenaline regime with its minimal cardiac side effects is entirely consistent with pharmacokinetic data in Goodman and Gilman's The pharmacological basis of therapeutics. $^{32}$

POSTADRENALINE CARE

Patients with significant anaphylactic reactions, including all those who received adrenaline, should be admitted to a monitored observation area (table 4). If their condition remains unstable, this should be an intensive care unit. Patients who are stable and appear to have recovered should still be observed for at least six to eight hours, as late deterioration may occur. This so called biphasic response was observed in up to $20 \%$ of the 25 patients in Stark and Sullivan's original description in $1986,{ }^{33}$ but more recent data on biphasic systemic anaphylaxis in an inpatient and outpatient study involving 94 patients by Douglas et al showed a much lower incidence of around $5 \% .^{34}$

It is essential to refer for allergy testing all patients discharged following a significant episode of anaphylaxis, to determine the cause of the reaction. ${ }^{1024}$ This may include cutaneous testing and radioimmunoassays for specific IgE. Desensitisation programmes may then be appropriate for selected patients. Others may require a self treatment adrenaline regime to avert or modify a serious attack should prodromal symptoms be experienced in the future. ${ }^{35}$ Those prescribed adrenaline by injection for self use (for example, Min-I-Jet or Epipen) must be fully trained in its use, as must their families. ${ }^{36}$ An alternative method of prehospital adrenaline delivery is high dose inhaled adrenaline by metered dose aerosol. Twenty $150 \mu \mathrm{g}$ activations of Medihaler-epi act rapidly and predictably to achieve both a high local and therapeutic systemic adrenaline level. ${ }^{19}$ Careful instruction in optimum inhaler technique is important.

\section{Steroids}

BENEFICIAL EFFECTS

The role of steroids in the management of acute anaphylaxis is limited to the prevention or shortening of protracted reactions, particularly those associated with bronchospasm. $^{2101213}$ This is despite their many

Table 5 Beneficial effects of steroids

$\uparrow$ Tissue responsiveness to $\beta$ adrenergic agonists

$\downarrow$ Mediator release

-Inhibition of phospholipase $\mathrm{A}_{2}$

-Inhibition of glutathione-s-transferase

-Uncoupling of receptor-effector systems

Downregulate cell activation

Prevent neutrophil and platelet aggregation

$\downarrow$ IgE expression theoretical benefits, which include an increase in tissue responsiveness to $\beta$ adrenergic agonists, ${ }^{13}$ inhibition of mediator release at three possible sites (by inhibition of phospholipase $A_{2}$, glutathione-s-transferase, and degranulation-possibly involving uncoupling of receptor-effector systems), ${ }^{37}{ }^{38}$ downregulating cell activation, ${ }^{39}$ prevention of neutrophil and platelet aggregation, ${ }^{40}$ and decreasing IgE receptor expression. ${ }^{41}$ (table 5). Even if given intravenously, steroids may take up to four to six hours to be maximally effective. ${ }^{42}$

SIDE EFFECTS

However, there are significant side effects reported with the use of steroids, such as steroid induced myopathy, sodium and potassium ion flux changes, and acute perineal pain with hydrocortisone sodium phosphate injection. ${ }^{4}$ Moreover, parenteral methylprednisolone, hydrocortisone and betamethasone and oral dexamethasone have all caused systemic anaphylaxis themselves. ${ }^{434}$ Although this is rare, the mechanisms include hapten formation to succinate esters or a reaction to an additive such as metabisulphite. Even more rare and unusual complications include coronary artery spasm following intramuscular betamethasone ${ }^{45}$ and sudden death or myocardial ischaemia following rapid infusion of high doses of corticosteroids. ${ }^{46}$ (table 6 ).

\section{INTRAVENOUS STEROIDS}

If intravenous steroids are used, standard doses of hydrocortisone of $5 \mathrm{mg} / \mathrm{kg}$ to a maximum of $200 \mathrm{mg}$, followed by $2.5 \mathrm{mg} / \mathrm{kg}$ six hourly, or methylprednisolone $125 \mathrm{mg}$ six hourly are recommended..$^{132429} 47$ (table 7). There appears little justification for the higher doses of methylprednisolone- $30 \mathrm{mg} / \mathrm{kg}$ - given in severe bronchospasm.

\section{ORAL STEROIDS}

Oral steroids, such as prednisone $40-50 \mathrm{mg}$ daily, avoid many of the above mentioned problems with intravenous steroids and should be used in all but the sickest patients. Oral steroids also form the cornerstone of management of recurrent idiopathic anaphylaxis. Prednisone $60-100 \mathrm{mg}$ orally daily, then alternate daily, and then tapered by no more than 5-10 mg per month is most effective in this rare condition. ${ }^{48}$ Prednisone $20 \mathrm{mg}$ twice daily for four days is a safe and effective adjunct to $H_{1}$ blocking antihistamine drugs in shortening the symptomatic and clinical course of acute urticaria, ${ }^{49}$ and is usually included in discharge medication, as discussed at the end of this review.

\section{Antihistamines}

The role of antihistamines in the management of acute anaphylaxis, although widespread, is controversial. Antihistamines and steroids should never be relied upon alone as first line treatment. $^{11235}$ Underlying the use of antihistamines are several paradoxes, which add to the confusion. 


\section{Table 6 Potential side effects of steroids}

Steroid induced myopathy

Sodium and potassium ion flux changes

Anaphylaxis (parenteral methylprednisolone, hydrocortisone, betamethasone; oral dexamethasone)

Perineal pain (hydrocortisone sodium phosphate injection)

Coronary artery spasm (intramuscular betamethasone)

Sudden death or myocardial ischaemia (rapid, high dose infusion)

PARADOXES IN THE USE OF ANTIHISTAMINES

Histamine has a variety of effects, principally on the respiratory and cardiovascular system, which may be deleterious (predominantly $\mathrm{H}_{1}$ mediated) or potentially beneficial (predominantly $\mathrm{H}_{2}$ mediated), as listed in table $8 .^{12} 2741425051$ The use of $\mathrm{H}_{2}$ receptor antagonists should therefore be associated with adverse effects as the $\mathrm{H}_{2}$ mediated beneficial effects are blocked. However, the opposite appears to be true. $\mathrm{H}_{2}$ receptor antihistamines such as cimetidine $300 \mathrm{mg}$ intravenously are effective in refractory anaphylactic shock unresponsive to adrenaline, fluids, steroids, and $\mathrm{H}_{1}$ receptor antihistamine given intravenously. ${ }^{52}{ }^{53}$ Effects other than direct myocardial histamine receptor interaction must be operating, and the intense vasodilatation seen is clearly mediated by both $\mathrm{H}_{1}$ receptors and $\mathrm{H}_{2}$ receptors. ${ }^{53-55}$ Also, although pruritus is said to be $\mathrm{H}_{1}$ receptor mediated, ${ }^{42} \mathrm{H}_{2}$ receptor blockers alone have proved effective clinically in relieving itching and wheal development, ${ }^{56}$ and in one series were more effective than $H_{1}$ receptor blockers in the treatment of acute urticaria. ${ }^{51}$

COMBINED $\mathrm{H}_{1}$ AND $\mathrm{H}_{2}$ RECEPTOR BLOCKER USE Thus the consensus regarding the use of antihistamines in acute anaphylaxis now favours a combination of an $\mathrm{H}_{1}$ and an $\mathrm{H}_{2}$ receptor blocker. ${ }^{23}{ }^{4257}$ Lieberman $^{57}$ states that for the prevention of drug induced anaphylactic and anaphylactoid reactions, combined $\mathrm{H}_{1}$ and $\mathrm{H}_{2}$ receptor blockade is more effective than $\mathrm{H}_{1}$ blockade alone; physiological rationale and a series of case reports indicate that combined $\mathrm{H}_{1}$ and $\mathrm{H}_{2}$ receptor blockade should also be more effective than $\mathrm{H}_{1}$ blockade alone in the treatment of anaphylaxis. Lorenz also showed superior efficacy of combined $\mathrm{H}_{1}$ and $\mathrm{H}_{2}$ receptor blockers in protecting against histamine related cardiorespiratory disturbances during routine anaesthesia. ${ }^{58}$

Table 7 Second line management of acute anaphylaxis (oxygen, adrenaline, and fluids are given first)

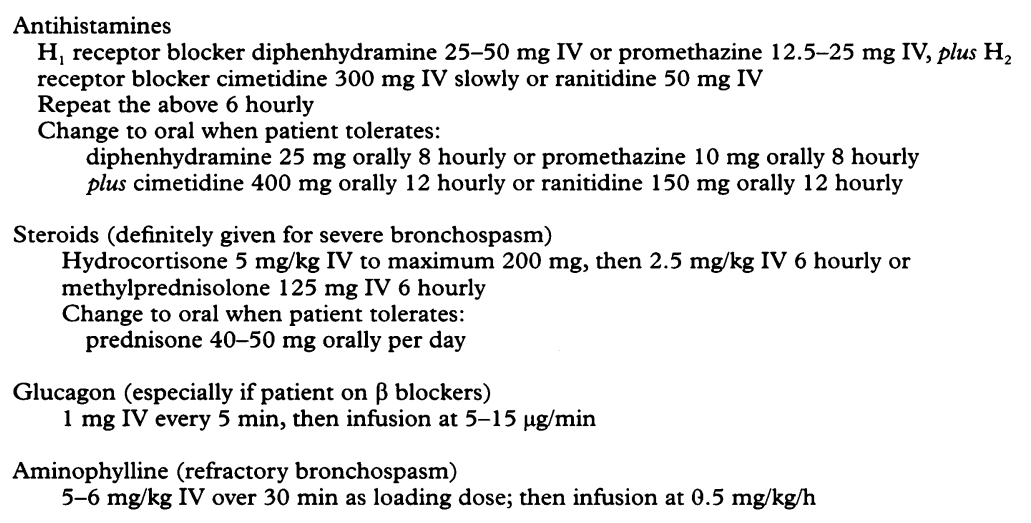

IV, intravenous.
SIDE EFFECTS AND LIMITATIONS

Antihistamines never have a central role in the management of anaphylaxis since the concentration of histamine in the immediate vicinity of a mast cell after degranulation is so great that by the time anaphylaxis is diagnosed, it is too late for a competitive blocker to be of value. Furthermore, antihistamines do not actually prevent mediator release, and mediators other than histamine are of equal biological importance..$^{59}$ In addition, there are important side effects related to the use of $\mathrm{H}_{1}$ receptor antihistamines, such as sedation, hypotension from $\alpha$ adrenergic blockade, confusion, and torsade de pointes, particularly if astemizole or terfenadine are combined with erythromycin. ${ }^{60}$ The risks of sedation are particularly relevant during outpatient treatment. Patients must be warned not to drive or operate machinery, especially if prescribed $\mathrm{H}_{1}$ receptor blockers (and to a much lesser extent $\mathrm{H}_{2}$ receptor blockers) $)^{51}$ (table 9).

\section{OPTIMAL ROLE OF ANTIHISTAMINES}

Antihistamines are of greatest use when the allergic condition is not life threatening and is progressing slowly, such as in angio-oedema and urticaria. ${ }^{55}$ The half life of angio-oedema may be longer than the duration of effect of any adrenaline given, and hence it may recur if treatment is not supplemented with antihistamines. ${ }^{10}$ Although acute urticaria may be self limited if untreated, ${ }^{61}$ most patients who present to hospital have disabling symptoms. $\mathrm{H}_{1}$ receptor blockers alone have traditionally been considered the primary treatment, ${ }^{62}$ but should now be given in combination with an $\mathrm{H}_{2}$ blocker (table 7). ${ }^{55}$ Subcutaneous adrenaline has also been recommended for itching and urticaria in milder forms of anaphylaxis, ${ }^{63}$ although it should be used in conjunction with antihistamines. ${ }^{64}$ Finally steroids should be added in acute urticaria, particularly in refractory cases. Doses of $20 \mathrm{mg}$ prednisone orally twice daily are safe and effective. ${ }^{49}$

\section{Fluids}

Over half the people who die from anaphylaxis succumb within the first hour. ${ }^{12}$ The principal causes of death in $75 \%$ of cases are asphyxia from upper airway oedema and hypoxia from severe bronchospasm. Death in the remaining $25 \%$ is related to circulatory failure with hypotension. ${ }^{65}$ This hypotension is multifactorial, but includes plasma losses of up to $50 \%$ of the circulatory volume. ${ }^{1}$ Therefore fluids, with oxygen and adrenaline, are essential first line treatment for severe anaphylaxis with shock. ${ }^{12}$

WHICH FLUID?

Crystalloid solutions such as normal saline or Ringer's lactate may be given rapidly at $10-20$ $\mathrm{ml} / \mathrm{kg}^{24}{ }^{27} 65$ Alternatively, colloids including albumin, dextran 70 , and gelatin preparations such as Haemaccel may be given, also at 10-20 $\mathrm{ml} / \mathrm{kg}$. ${ }^{30} 3540{ }^{66}$ Large volumes of fluid are often required. Measurement of central venous pressure and packed cell volume help guide treatment. Although both solutions have been used successfully, the three- to sixfold extra 
Table 8 Deleterious and potentially beneficial histamine receptor effects

$\mathrm{H}_{1}$ receptor:

$\uparrow$ Atrioventricular conduction delay

Coronary vasoconstriction

Initial fall in blood pressure (with an infusion)

Bronchospasm

Pruritus

$\mathrm{H}_{2}$ receptor:

Coronary vasodilatation

Positive inotrope

Positive chronotrope

Bronchodilatation

Sustained hypotension (with an infusion)

Negative feedback inhibition histamine release

requirement with crystalloids, their dilution of colloid oncotic pressure, and the longer lasting capillary leakage which prolongs resuscitation are factors favouring the use of colloids in anaphylactic shock (table 2).

FLUID USE ALONE

Some authorities have used fluids alone in anaphylactic shock $^{67}$ without vasoconstrictor drugs, for instance following reactions to contrast media administration, and question the central role of adrenaline. ${ }^{68}$ Others have found the opposite and have been unable to resuscitate patients with fluid alone. ${ }^{69}$ There are compelling arguments against using fluid alone, such as the additional benefit of adrenaline in bronchospasm, urticaria, and angiooedema, its ability to stabilise mast cells, reducing further mediator release, and the rapidity of its administration intramuscularly or subcutaneously, when intravenous access is difficult or delayed. ${ }^{1}$

CONCERNS WITH HAEMACCEL

A concern over the use of colloids, particularly polygeline (Haemaccel), is that this preparation itself is known to have caused anaphylactic reactions. Anaphylaxis has been reported rarely following the use of Haemaccel during general anaesthesia ${ }^{70}$ and epidural anaesthesia, ${ }^{71}$ although the exact mechanism is unclear. The makers claim that following modification of the manufacturing process Haemaccel is now nonantigenic and that possible anaphylactoid reactions may be minimised by pretreatment with combined $\mathrm{H}_{1}$ and $\mathrm{H}_{2}$ histamine receptor blockers $^{72}$ (as confirmed by Lorenz ${ }^{58}$ ). They also advise against rapid infusion to normovolaemic individuals. In practice, although various colloids may produce anaphylactic and anaphylactoid reactions, these rarely if ever occur in already shocked patients, presumably because of the protective effects of their own sympathoadrenal response to the shock. ${ }^{35}{ }^{41}$

\section{Glucagon}

Patients taking $\beta$ blocking drugs appear to be at increased risk of anaphylaxis and have more severe reactions that prove difficult to treat. ${ }^{73}$

Table 9 Potential side effects of antihistamine

Sedation $\left(\mathrm{H}_{1}>\mathrm{H}_{2}\right)$

Hypotension ( $\alpha$ blockade)

Confusion

Torsade de pointes (especially astemizole or terfenadine plus erythromycin)
Standard treatment with adrenergic agents may be ineffectual and theoretically causes a predominance of unopposed $\alpha$ adrenergic effects leading to augmented mediator release, bradycardia, bronchoconstriction, and dangerously exaggerated systemic pressor effects. ${ }^{75}$ Although aggressive management with adrenaline, fluids, dopamine, and isoprenaline may work, many authorities recommend using glucagon, particularly for refractory hypotension. ${ }^{1324763}$ Glucagon in a dose of $1 \mathrm{mg}$ intravenously repeated every five minutes, followed by an infusion at $5-15 \mu \mathrm{g} / \mathrm{min}$, raises intracellular cyclic AMP by a calcium dependent stimulation which does not involve $\beta$ adrenergic receptors, causing positive inotropic and chronotropic cardiac effects. ${ }^{76}$ It is necessary to be careful with its use because nausea, vomiting, dizziness, hypokalaemia, and blood sugar abnormalities may occur ${ }^{6376}$ (table 7 ).

\section{Aminophylline}

Aminophylline may be useful for severe anaphylactic bronchospasm resistant to adrenaline and steroids. Although considered dangerous by some, the combination of aminophylline and adrenaline produces no greater incidence of serious arrhythmias such as ventricular fibrillation than would be expected with either drug used alone. ${ }^{77}$ It was used safely in over 200 cases in one series without mishap, with apparent improvement in most patients. ${ }^{35}$

\section{BENEFICIAL EFFECTS AND DOSE}

Beneficial effects include bronchodilatation, stimulation of respiratory muscles, pulmonary vasodilatation, and a rise in intracellular cyclic AMP through inhibition of phosphodiesterase, theoretically adding to the inhibiting effect of adrenaline on mediator release. ${ }^{30}$ However, it should be avoided in anaphylactic shock as worsening of hypotension and unpredictable cardiac toxicity occur. ${ }^{2}$

The recommended dose is $5-6 \mathrm{mg} / \mathrm{kg}$ intravenously over 30 minutes, with full cardiac monitoring. A lower infusion rate is used in older patients, in those taking drugs that interfere with aminophylline metabolism such as cimetidine or erythromycin, and in patients with liver or cardiac failure. Higher rates may be used in fit, younger patients and cigarette smokers. ${ }^{2}$ Nebulised salbutamol may be used in addition for bronchospasm ${ }^{2}{ }^{10}$ (table 7).

\section{Discharge planning}

PERIOD OF OBSERVATION

All patients with significant anaphylactic reactions, including those who received adrenaline, should be observed for a minimum of six to eight hours after apparent recovery, as late deterioration may occur. ${ }^{33}{ }^{34}$ Patients with unstable vital signs or with protracted or resistant anaphylaxis should be monitored in an intensive care area. Others who remain well may then be discharged if no further symptoms recur, as discussed earlier (table 4). 
Table 10 Discharge plan following acute anaphylaxis

\author{
Discharge drugs for 3 days: \\ Diphenhydramine $25 \mathrm{mg}$ orally 8 hourly or promethazine $10 \mathrm{mg}$ orally 8 hourly plus \\ cimetidine $400 \mathrm{mg}$ orally 12 hourly or ranitidine $150 \mathrm{mg}$ orally 12 hourly \\ Prednisone $40-50 \mathrm{mg}$ orally daily \\ Refer to allergist: \\ All significant or recurrent attacks, or stimulus unknown or unavoidable: \\ give detailed letter documenting exact nature and outcome of reaction
}

DISCHARGE DRUGS AND ALLERGY REFERRAL

Drug treatment should be continued for three days after hospital discharge. ${ }^{23} 2447$ Oral antihistamines such as the $\mathrm{H}_{1}$ receptor blocker diphenhydramine $25 \mathrm{mg}$ eight hourly and an $\mathrm{H}_{2}$ receptor blocker such as cimetidine $400 \mathrm{mg}$ 12 hourly are suitable. Although some physicians prefer to use one or the other-choosing an $\mathrm{H}_{2}$ receptor blocker to avoid drowsiness in those patients wishing to drive or return to work $^{24}$-it is logical to give both together. ${ }^{57}$ Oral prednisone $40-50 \mathrm{mg}$ daily is recommended in addition, to reduce the likelihood of relapse of symptoms ${ }^{23}$ and to augment the effects of the antihistamine. ${ }^{49}$ All patients are instructed to return immediately if symptoms recur. Most should be referred for allergy testing, particularly if the attack of anaphylaxis was significant, recurrent, or the stimulus unknown or unavoidable ${ }^{1024304763}$ (table 10).

\section{Self limiting anaphylaxis}

Some patients recover from anaphylaxis with little or no treatment, ${ }^{61}$ or following apparently unconventional treatment that omits adrenaline. ${ }^{78}$ The explanation lies with the cellular basis of the anaphylactic reaction itself. Primary mast cell and basophil mediators such as neutrophil chemotactic factor, eosinophil chemotactic factor, and leukotriene $\mathrm{LTB}_{4}$ attract a variety of cells to the area including platelets, neutrophils, eosinophils, lymphocytes, and monocytes. These newly recruited cells in turn release secondary mediators which may augment the reaction, causing a further wave of mast cell degranulation and leading to a vicious cycle of ongoing inflammation associated with increased vascular permeability. ${ }^{18} 7980$ However, some secondary mediators actually inhibit anaphylaxis, particularly those released from eosinophils. Histaminase breaks down histamine, arylsulphatase B inactivates leukotrienes, and phospholipase D destroys platelet activating factor. ${ }^{13}$ Histamine itself, through $\mathrm{H}_{2}$ receptors, raises intracellular cyclic AMP, thereby reducing mediator release. ${ }^{4151}$ Thus in less severe reactions the anaphylactic process may itself be self limiting. Unfortunately, it is impossible to predict disease activity, so all patients should initially be observed for symptom progression.

\section{Conclusions}

Anaphylaxis may be mild or severe, gradual in onset or fulminant, involve multiple organ systems or present with isolated shock or wheeze, and may or may not be IgE mediated. Therefore a simple treatment algorithm covering all possible situations is unrealistic. However, treatment protocols that work clinically are available, such as suggested by Gavalas et al in this issue of the journal ${ }^{81}$ ( $\mathrm{p} \mathrm{96)}$; such protocols should be known to clinicians and even inexperienced doctors should be familiar with them. Adrenaline, oxygen, and fluids are accepted first line treatments. Care with the route, dose, concentration, and speed of delivery of adrenaline in particular underpin its safety and efficacy. Antihistamines, steroids, glucagon, and aminophylline may be considered second line drugs, but require equal thought in their use, especially in weighing up the possible side effects with their perceived benefits. Finally, once the initial drama has settled, proactive discharge planning including allergy referral where appropriate ensures both the immediate and long term safety of the patient, and protects against further, often unheralded, attacks of anaphylaxis.

I am indebted to Carol Bicknell and Jennifer Nelson for their tireless efforts in the preparation of this paper.

1 Fisher MM. Anaphylaxis. Disease a Month 1987;33:44179.

2 Bochner BS, Lichtenstein LM. Anaphylaxis. N Engl J Med 1991;324:1785-90.

3 Fisher MM. Treating anaphylaxis with sympathomimetic drugs. BMJ 1992;305:1 107-8.

4 Brueton MJ, Lortan JE, Morgan DJR, Sutters CA. Management of anaphylaxis. Hosp Update 1991;17:386-98.

5 Hedner T, Samuelsson O, Lunde H, Lindholm L, Andren $\mathrm{L}$, Wiholm B-E. Angio-oedema in relation to treatment $\mathrm{L}$, Wiholm B-E. Angio-oedema in relation to treatment
with angiotension converting enzyme inhibitors. BMJ with angiotensio

6 Smith GB, Taylor BL. Management of anaphylaxis. Hosp Update 1991;17:833.

7 Watt JWG, Wiles JR. Management of anaphylaxis. Hosp Update 1991;17:833-4.

8 Lip GYH, Metcalfe MJ. Adrenaline in allergic emergencies. BMJ 1992;304:1443.

Smith GB, Taylor BL. Adrenaline in allergic emergencies. BMJ 1992;304:1635.

10 Fisher M. Treatment of acute anaphylaxis. BMJ 1995;311: 731-3.

11 Fisher M. Treatment of acute anaphylaxis. BMJ 1996;312: 637-8.

12 Brown AFT. Anaphylactic shock: mechanisms and treatment. J Accid Emerg Med 1995;12:89-100.

13 Hollingsworth HM, Giansiracusa DF, Upchurch KS. Anaphylaxis. J Intensive Care Med 1991;6:55-70.

14 Barach EM, Nowak RM, Lee TG, Tomlanovich MD. Epinephrine for treatment of anaphylactic shock. JAMA 1984;251:2118-22.

15 Kaliner M, Austen KF. Cyclic AMP, ATP and reversed anaphylactic histamine release from rat mast cells. J Immunol phylactic histamine

16 Stoloff R, Adams SL, Orfan N, Harris KE, Greenberger PA, Patterson R. Emergency medical recognition and management of idiopathic anaphylaxis. J Emerg Med 1991;10: 693-8.

17 Joint Formulary Committee. Allergic emergencies. In: British national formulary. London: British Medical Association and Royal Pharmaceutical Society of Great Britain, 1996:130.

$18 \mathrm{Sim}$ TC. Anaphylaxis. How to manage and prevent this medical emergency. Postgrad Med 1992;92:277-96.

19 Heilborn H, Hjemdahl P, Daleskog M, Adamsson U. Comparison of subcutaneous injection and high-dose inhalation of epinephrine-implications for self-treatment to prevent anaphylaxis. J Allergy Clin Immunol 1986;78:1 174-9.

20 Lockey RF, Fox RW. Allergic emergencies. Hosp Med 1979; 15:64-8.

21 Barbar JM, Budassi SA. In: Mosby's manual of emergency care: practices and procedures. St Louis: CV Mosby, care: practices

22 Costa AJ. Anaphylactic shock. Postgrad Med 1988;83:36873

23 Zull DN. Preventing fatalities from anaphylaxis: an emergency medicine physician's perspective. Allergy Proc 1995; gency medici
$16: 113-4$.

24 Zull DN. Anaphylaxis. In: Harwood-Nuss A, Linden C, Luten $\mathrm{R}$, Shepherd $\mathrm{R}$, Wolfson AB, eds. The clinical practice of emergency medicine, 2nd ed. Philadelphia: LippincottRaven, 1996:929-32.

25 Sullivan TJ. Cardiac disorders in penicillin-induced anaphylaxis. Association with intravenous epinephrine therapy. JAMA 1982;248:2161-2.

26 Roberts-Thomson P, Heddle R, Kupa A. Adrenaline and anaphylaxis. Med J Aust 1985;142:708.

27 Felix SB, Baumann G, Niemczyk $M$, Hashemi T, Ochsenfeld $G$, Ahmad $Z$, et al. Effects of histamine $\mathrm{H}_{1}$ and $\mathrm{H}_{2}$ receptor antagonists on cardiovascular function during systemic anaphylaxis in guinea pigs. Agents Actions 1991;32: 245-52. 
28 Del Balzo U, Polley MJ, Levi R. Activation of the third complement component $\left(\mathrm{C}_{3}\right)$ and $\mathrm{C}_{33}$ generation in cardia anaphylaxis: histamine release and associated inotropic an chronotropic effects. J Pharmacol Exp Ther 1988;246: 911-6.

29 Levy JH, Levi R. Diagnosis and treatment of anaphylactic/ anaphylactoid reactions. Monogr Allergy 1992;30:130-44.

30 Fisher MM. Anaphylaxis. In: Oh TE, ed. Intensive care manual, 4th ed Oxford: Butterworth-Heinemann, 1996: 509-11.

31 Nimmo WS, Aitkinhead AR, Clarke RSJ, Weller RM. Anaphylactic reactions associated with anaesthesia. London: phylactic reactions associated with anaesthesia. London: Associat 1990.

32 Hoffman BB, Letkowitz RJ. Catecholamines, sympathomimetic drugs and adrenergic receptor antagonists. In: Hardman JG, Limbird LE, eds. Goodman and Gilman's the phar macological basis of therapeutics, 9th ed. New York: McGraw-Hill, 1996:199-248.

33 Stark BJ, Sullivan TJ. Biphasic and protracted anaphylaxis. J Allergy Clin Immunol 1986;78:76-83.

34 Douglas DM, Sukenick E, Andrade P, Brown JS. Biphasic systemic anaphylaxis: an inpatient and outpatient study. J Allergy Clin Immunol 1994;93:977-85.

35 Fisher MM, Baldo BA. Acute anaphylactic reactions. Med J Aust 1988;149:34-8

36 Davies H, Harris J, Kakoo A. Patients should be taught how to inject adrenaline. BMJ 1996;312:638.

37 White MV, Igarashi Y, Lundgren JD, Shelhamer J, Kaliner J. Hydrocortisone inhibits rat basophil leukaemia cell mediator release induced by neutrophil-derived histamine releasing activity as well as by anti-IgE. J Immunol 1991;147: ing activity

38 Di Rossa M, Flower RJ, Hirata F, Parente L, Russo-Marie F Anti-phospholipase protein. Prostaglandins 1994;28: Anti-phospholipase protein. Prostaglandins 1994;28:

39 Huston DP, Bressler RB. Urticaria and angioedema. Med Clin North Am 1992;76:805-40.

40 Perkin RM, Anas NG. Mechanisms and management of anaphylactic shock not responding to traditional therapy. Ann Allergy 1985;54:202-8.

41 McKinnon RP, Wildsmith JAW. Histaminoid reactions in anaesthesia. Br J Anaesth 1995;74:217-28.

42 Prescott Atkinson T, Kaliner MA. Anaphylaxis. Med Clin North Am 1992;76:841-55.

43 Manhart AR, Egwiekhor OA, Jahns BE, Rynn KO. Fata anaphylactic shock to hyoscine and diphenhydramine. A doubtful diagnosis. Clin Toxicol 1995;33:189-90.

$44 \mathrm{McNamara}$ RM. Anaphylaxis after intravenous corticosteroid administration. J Emerg Med 1986;4:213.

45 Machiels J-P, Jacques J-M, de Meester A. Coronary artery spasm during anaphylaxis. Ann Emerg Med 1996:27: 674-5.

46 Erstadt BL. Severe cardiovascular adverse effects in association with acute, high-dose corticosteroid administration. ation with acute, high-dose corticos

47 Salomone JA. Anaphylaxis and acute allergic reactions. In Tintinalli J, Ruiz E, Krome RL, eds. Emergency medicine: a Tintinalli J, Ruiz E, Krome RL, eds. Emergency medicine: a
comprehensive study guide, 4th ed. New York: McGraw Hill, comprehensive

48 Patterson R, Stoloff RS, Greenberger PA, Grammer LC, Harris KE. Algorithms for the diagnosis and managemen of idiopathic anaphylaxis. Ann Allergy 1993;71:40-4.

49 Pollack CV, Romano TJ. Outpatient management of acut urticaria: the role of prednisone. Ann Emerg Med 1995;26:547-51.

50 Serafin WE, Austen KE. Mediators of immediate hypersen sitivity reactions. N Engl J Med 1987;317:30-4

51 Moscati RM, Moore GP. Comparison of cimetidine and diphenhydramine in the treatment of acute urticaria. An Emerg Med 1990;19:12-15.

52 Yarbrough JA, Moffitt JE, Brown DA, Stafford CT. Cimetidine in the treatment of refractory anaphylaxis. Ann Allergy $1989 ; 63: 235-8$

53 De Soto H, Turk P. Cimetidine in anaphylactic shock refractory to standard therapy. Anesth Analg 1989;69: 264-5.

54 Marshall I. Characterization and distribution of $\mathrm{H}_{1}$ and $\mathrm{H}_{2}$ receptors in precapillary vessels. J Cardiovasc Pharmacol 1984;6(suppl 4):S587-97.
55 Runge JW, Martinez JC, Caravati EM, Williamson SG, Hartsell SC. Histamine antagonists in the treatment of acute allergic reactions. Ann Emerg Med 1992;21:237-42.

56 Mayumi H, Kimura S, Asano M, Shimokawa T, Au-Yong $\mathrm{T}-\mathrm{F}$, Yayama T. Intravenous cimetidine as an effective treatment of systemic anaphylaxis and acute allergic skin reactions. Ann Allergy 1987;58:447-50.

57 Lieberman $P$. The use of antihistamines in the prevention and treatment of anaphylaxis and anaphylactoid reactions. J Allergy Clin Immunol 1990;86:684-6.

58 Lorenz W, Duda D, Dick W, Sitter H, Doenicke A, Black A et al. Incidence and clinical importance of perioperative histamine release: randomised study of volume loading and antihistamines after induction of anaesthesia. Lancet 1994 343:933-40.

59 Valentine $M D$. Anaphylaxis and stinging insect hypersensitivity. JAMA 1992;268:2830-3.

60 Ben-David J, Zipes DP. Torsades de pointes and proarrhythmia. Lancet 1993;341:1578-82.

61 Soter NA. Treatment of urticaria and angioedema: low sedating $\mathrm{H}_{1}$-type antihistamines. J Am Acad Dermatol sedating $\mathrm{H}_{1}$-type

62 Kennard CD, Ellis CN. Pharmacologic therapy for urticaria. J Am Acad Dermatol 1991;25:176-89.

63 Yunginger JW. Anaphylaxis. Curr Prob Pediatr 1992;22 $130-47$.

64 Metzger WJ. Urticaria, angioedema and hereditary angioedema. In: Patterson R, ed. Allergic diseases: diagnosis and treatment, 4th ed. Philadelphia: J B Lippincott, 1993:33151 .

65 Netzel MC. Anaphylaxis: clinical presentation, immunologic mechanisms and treatment. J Emerg Med 1986;4: logic mech

66 Carlson RW, Bowles AL, Haupt MT. Anaphylactic, anaphylactoid and related forms of shock. Crit Care Clin 1986;2 347-72.

67 Waldhausen E, Keser G, Marquardt B. Anaphylactic shock. Anaesthetist 1987;36:150-8.

68 Van Sonneberg E, Nef CC, Pfister RC. Life-threatening hypotensive reactions to contrast media administration. Comparison of pharmacologic and fluid therapy. Radiology 1987;162:15-19.

69 Ponten J, Biber B, Henriksson BA. Successful vasoconstrictor therapy of anaphylactoid reactions during induction of anaesthesia. A report of two cases. Acta Anaesthesiol Scand 1985;29:639-42.

70 Duffy BL, Hardy JN, Fuller WR, Peake SL. Cardiac arrest following Haemaccel. Anaesth Intensive Care 1994;22 90-2.

71 Freeman MK. Fatal reaction to Haemaccel. Anaesthesia 1979;34:341-3.

72 Gajek H. Cardiac arrest following Haemaccel: comment. Anaesth Intensive Care 1994;22:743.

73 Toogood JH. Risk of anaphylaxis in patients receiving betablocker drugs. J Allergy Clin Immunol 1988;1:1-5.

74 Lang DM, Alpern MB, Visintainer PF, Smith ST. Increased risk for anaphylactoid reactions from contrast media in patients on beta blockers or with asthma. Ann Intern Med 1991;115:270-6.

75 Raebel MA. Potentiated anaphylaxis during chronic betablocker therapy. Drug Intelligence and Clinical Pharmacology 1988;22:720-7.

76 Pollack CV. Utility of glucagon in the emergency department. J Emerg Med 1993;11:195-205.

77 Josephson GW, Kennedy HL, Mackenzie EJ. Cardiac dysrrhythmias during the treatment of acute asthma. Chest 1980;78:429-35.

78 Luke LC. Surviving the journey is a good prognostic indicator. BMJ 1995;311:1434.

79 Soto-Aguilar MC, de Shazo RD. Anaphylaxis. Why it happens and what to do about it. Postgrad Med 1987;82:154-70.

80 Borish L, Joseph BZ. Inflammation and the allergic response. Med Clin North Am 1992;76:765-87.

81 Gavalas M, Wallis D, Sadana A, Metcalf S. Guidelines for the management of anaphylaxis in the emergency department. J Accid Emerg Med 1998;15:96-8. 